The Turkish Online Journal of Design, Art and Communication - TOJDAC

ISSN: 2146-5193, September 2018 Special Edition, p.978-981

\title{
THE RUSSIAN LAW EFFECTIVENESS AND SOCIOCULTURAL CONTEXT
}

\author{
Nikolay V. Petrov \\ $\mathrm{PhD}$ in Law \\ Associate Professor of the Civil Law and Procedure Department of the Federal State Autonomous \\ Educational Institution for Higher Education "North-Caucasus Federal University" \\ petrov_sksi@mail.ru \\ Irina V. Petrova \\ $\mathrm{PhD}$ in Law, Associate Professor \\ Dean of the Law Faculty of the Autonomous Non-profit Organization for Higher Education "North- \\ Caucasus Social Institute" \\ petrova_sksi@mail.ru \\ Aleksandr P. Fedorovskiy \\ Doctor of Philosophy, Professor \\ Vice-Rector for Science and Public Relations of the Autonomous Non-profit Organization for Higher \\ Education "North-Caucasus Social Institute" \\ fedorovskiy@rambler.ru
}

\begin{abstract}
The article deals with the problem of dependence of the application effectiveness of legal norms on their correspondence to the present sociocultural context of the society. The author criticizes the voluntary approach to lawmaking, which doesn't contain a conceptual appeal to the historically formed value corpus, cultural traditions and mentality peculiarities, and also to the life world's content. The authoring team formulates the basic sociocultural imperatives, the observance of which, in the process of developing legal norms, is intended to provide a sufficiently high level of public sense of justice.
\end{abstract}

Keywords: legal norm, cultural traditions, legal awareness, life world, legal effectiveness, lawmaking anarchism, lawmaking, mentality, social reality, lawmaking apriorism, legal representations.

\section{INTRODUCTION}

One of the prominent places among the priority problems of modern Russian society is taken by the effectiveness improvement problem, both in lawmaking and in law enforcement practices. However, we will not dwell on the second aspect of the problem in this article, because we believe that the "legal product" will not find its "consumer" until it will correspond to those intended ideas about it, which exist in the collective consciousness of Russians. In this sense, the mechanisms for "advancing" the legal product are less significant than the product itself and the public request for it. If the laws "don't work", this isn't only because of imperfect ways of their implementation, but, first of all, because of lack of a broad and stable legal consensus in relation to norms of the current legislation in our society. This way, we think that our immediate task is to propose the most general approaches to formation of the legislative process, the mandatory ground for which would be the consideration of a content of deep public consciousness structures, attributive peculiarities of the domestic mentality, a historical experience of people and their cultural traditions.

Since the preparation of this article is conducted on the conceptual domain of a philosopho-legal, sociological and legal thought, and we see the methodological support for solution of this problem only in the interdisciplinarity horizon, then we are interested in its understanding directly by legal experts, who deal not only with legal theory, but also capable to assess the current state of the law practice. And it is important at this point to get an idea, even not so much about the explicit understanding of our raised problem by experts, but its intuitive awareness by the professional legal community. Besides, it is important to see those outlines of the touched topic, which are thematized by the jurisprudential discourse itself.

Submit Date: 10.07.2018, Acceptance Date: 25.08.2018, DOI NO: 10.7456/1080SSE/135

Research Article - This article was checked by Turnitin

Copyright (C) The Turkish Online Journal of Design, Art and Communication 
It isn't difficult to see that works of many lawyers also contain the idea of ineffectiveness of modern Russian legislation, which shows not only their understanding of existence of the problem as such, but also existence of relevant representations concerning the nature of its determination. So, for example, the idea of presence of peculiar "lacunae" in the Russian legislation, the existence of which is caused by violations of the sequence in implementation of the lawmaking procedures, when the law principles don't precede the legal norms, don't act as their prerequisites, which is a violation of the lawmaking logic, is expressed in the work of D.A. Smirnov and K.A. Strus. "The general analysis of application of law principles in the context of the legal basis - noted by the specified authors - allow to note the absence of direct regulatory influence of law principles on the legal regulation system, since law principles have no priority in implementation of specifically determined legal norms, which have to correspond to them; law principles can't be a basis for a rendered enabling legislation" [Smirnov D.A., Strus K.A., 2015: 3]. Thus, the fact that we determined as a lack of consensus on legal matters in the society, sounds like "a decrease in effectiveness of legal regulation as a whole", in terms of the legal science [Ibid].

However, the above statement also shows the well-known limitation of the denotative and, moreover, conceptual framework of the legal science. Jurisprudence deals with the concept of the "law principle" from the aprioristic point of view, without conducting the necessary explicit procedures, without raising the question of the original content of this principle. And there is a clear threat that misinterpreted law principles, that is formulated without taking into account the corresponding sociocultural context, even in case of their right localization in the legal creativity logistics, will not contribute to increase in the law effectiveness. That way, in order to avoid the law-making anarchism, it is necessary to turn to what precedes the law principle as a basic unit of the legal system as a whole.

It is thought that the fundamental analysis should be based on the anthropo-axiological approach, which has proved its productive efficiency in the widest range of social studies. The essence of this approach is simultaneous interpretation of a person as a biological object and as a carrier of a particular set of values and meanings. Provided that the institutional, including legal, model, applied in the society, correlates with the biological nature and sociocultural structure of a social actor, then there is a progressive development of social subsystems and the society as a whole.

Then, the lawmaking process should be preceded by large-scale social studies examining the multilevel value world of our living in the monitoring regime, to whose results it could correspond. "An individual's reaction to social processes, an orientation to support, reproducing or blocking social changes" depends on the degree to which they will be successful [Przhilenskiy V.I., Ogorodnikov A.Yu., 2016: 67].

Legal experts may argue that the law principles, as well as the lawmaking process as a whole, are derived from an analysis of the specifics of social empiricism, understanding and reinterpretation of factual materials. This is really so at a first glance beyond the immediacy of understanding that the legally interpreted empirical reality isn't perceived in itself, but through some prism of a particular value system, has a pronounced personal articulation, it is based on many stereotypes, emotions and even the human subconscious. And only being taken in this completeness, the empirical space has an opportunity to be a target for legal reflection, to lay the groundwork for further lawmaking.

Moreover, not only the continuum of sociocultural empirism as such should be understood as a meaningful and sense-making matrix of effective law-making. This includes the separately taken fact, the reference to which, as it is commonly believed, guarantees the "cleanliness" of the law enforcement decision. Criticizing a narrow positivistic view of this empirism segment, L.I. Voskobitova and V.I. Przhilenskiy point up the fact that "the legal theory doesn't pay enough attention to a study and definition of the "fact" as a theoretical construction providing an objective basis for a law-enforcement act" [Voskobitova L.A., Przhilenskiy V.I., 2016: 781].

Seeking to subordinate the legislative process to the logic of social development of Russian society, we inevitably face the dilemma of its ethno-cultural and ethno-confessional diversity and the legal requirement of universality of the current legislation. Indeed, "Russia was always like an aggregation of multidirectional value vectors, acted as a carrier of contradictory ideas and completely opposite first

Submit Date: 10.07.2018, Acceptance Date: 25.08.2018, DOI NO: 10.7456/1080SSE/135

Research Article - This article was checked by Turnitin

Copyright (C) The Turkish Online Journal of Design, Art and Communication 
principles, it tried on different images with combined light and dark lines, where rationality was adjacent to irrationality, Europeanness - to backwardness, and revolutionism - to evolutionism" [Zakharova M.V., Przhilenskiy V.I., 2016: 7].

But, in fact, the marked dilemma seems difficult only at a first glance. Its supposed difficulty rests only on dogmatized ideas about the so-called mandatory nature of legal universalism. At the same time, the falseness of such views is evidenced even by the quite proven experience of rather recent national history in that its segment, where the question is a differentiated approach to drafting legal norms, under which those were determined by specific sociocultural identity of Soviet ethnoses. Suffice it to recall that, under the general permitted marriage age of 18 years, the lower age threshold for marriage for women was lowered to 16 in a number of republics of the Soviet Union, including those located in the European part of the country. The current example of an adogmatic understanding of law is an existence of Article 3 in the Federal Law "On Arms" 150-FZ in the current Russian legislation, permitting "cold edged weapons intended for bearing with the Cossack form, as well as with national costumes of the Russian Federation, the attributes of which are determined by the Government of the Russian Federation".

The requirement to consider a sociocultural context in producing laws over the long term can solve another problem related to the peculiarities of national legal consciousness, namely, to overcome the legal nihilism inherent in it, to stop the centuries-old conflict between the society and state, which is, as a rule, in latent forms, but can also escalate radically. The fact is that the historical formation of the society consciousness occurred under the strongest influence of religious maxima, the content of which was in violent contrast with lawmaking and law enforcement practice at a specific empirical level. An unintentional comparison of the existing realities with the sacred ideal with the need has provided the genesis and further strengthening of the nihilistic moods turned both against the laws and against those, who executed them. It isn't a stretch to consider that the legal nihilism has, by now, become one of the most noticeable attributes of public consciousness. We see the remediation of the existing situation in introduction of the practice of sociocultural examination of newly adopted laws, one of the mandatory procedures of which will be the so-called "test for justice", assessing the probabilistic ethical attitude to them on the part of the society, as well as the degree of understanding of their appropriateness.

Achievement of the required legal loyalty indicators is also possible through erosion of the state's negative image perceived by mass consciousness as a subject of legal dictature. We think that there is no need to expound that the fundamental official formula proclaiming the people as the main legal source is actually perceived as a ritual declaration deprived of all empirical correlates. In this regard, we should pay more attention to the relevant experience of national history, which designates the opportunity and necessity of multiplication of legal subjects, as well as of law enforcement activities. The flashback of development of the Russian legal system gives a lot of examples when the solution of many important legal issues was transferred to the seats that increased the effectiveness of control over execution of decisions and provided them consensually. In this case, the question is semiformal institutions, such as a rural gathering, eldership or kagal administration. The emergence of similar structures under municipalities or at the civil society level could eliminate the situation of legal isolationism, in which the modern average Russian found himself, who has a low legal awareness and legal literacy level and prefers to resolve legal conflicts outside the legal boundaries. Such institutions, in case of their emergence, could be considered as a kind of "incubators" of full, in legal relations, social actors with specific experience of legally-oriented activities.

In conclusion of this article, we should dwell on some fundamentally important points. First, the reason for its preparation wasn't the development of some directive text of an invariant nature, but rather the performance of mental experiment aimed at improvement of effectiveness of efforts taken in the field of lawmaking. Second, the authors suppose the principle multiplicity of the ways to solve the designated problem, the existence of the corresponding resource base is recognized. Third, this is our principled position that the sociocultural context of the society has to be considered in the course of development of the legislation, and disputes on this topic can only be conducted with respect to specific forms and methods, but beside the question. The domestic sociocultural retrospective is distinguished by an extremely high informativeness level, which allows to draw all necessary lessons

Submit Date: 10.07.2018, Acceptance Date: 25.08.2018, DOI NO: 10.7456/1080SSE/135

Research Article - This article was checked by Turnitin

Copyright (C) The Turkish Online Journal of Design, Art and Communication 
The Turkish Online Journal of Design, Art and Communication - TOJDAC

ISSN: 2146-5193, September 2018 Special Edition, p.978-981

from it, including for optimization of the legal sphere. And if this isn't done, then there will be "an inevitable punishment for back lessons" [Zakharova M.V., Przhilenskiy V.I., 2017: 211].

\section{REFERENCES}

Voskobitova L.A., Przhilenskiy V.I. Evolution of the notion of fact: issues of legal cognition and law enforcement practices // Russian Journal of Criminology. 2016. No. 4.

Przhilenskiy V.I., Ogorodnikov A.Yu. Axiological foundations of social engineering: prospects of modernization of the Russian society // Sociological studies. 2016. No. 4.

Przhilenskiy V., Zakharova M. Which Way is the Russian Double-Headed Eagle Looking? // Russian Law Journal. Volume 4 (2016) Issue 2.

Przhilenskiy V., Zakharova M. Two Portraits on the Background of the Revolution: Pitirim Sorokin and Mikhail Reisner // Russian Law Journal. Volume 5 (2017) Issue 4.

Smirnov D.A., Strus K.A. General Scientific Analysis of Implementation of Principles of Law in the Contemporary Russian Legal Basis // Indian journal of Science and Technology. Vol. 8 (S10) December 2015. 